\title{
PELATIHAN PEMANDU WISATA BAHARI DI KAWASAN KONSERVASI PENYU DI DESA APAR KECAMATAN PARIAMAN UTARA KOTA PARIAMAN
}

\author{
Khairudin $^{1}$, Karmila Suryani ${ }^{2}$ \\ ${ }^{1}$ Program Studi Pendidikan Matematika, FKIP, Universitas Bung Hatta \\ ${ }^{2}$ Program Studi Pendidikan Teknik Informatika dan Komputer, FKIP, Universitas Bung Hatta \\ Jl. Bagindo Aziz Chan Jl. By Pass, Aie Pacah, Kota Padang \\ ${ }^{1}$ e-mail: khairuddin@bunghatta.ac.id
}

\begin{abstract}
Abstrak
Artikel ini mendeskripsikan pembentukan masyarakat yang sadar wisata dan melatih pemandu wisata bahari yang bertaraf internasional serta membentuk wadah organisasi pemandu yang bekerja secara profesional merupakan tujuan dari program hibah KKN-PPM. Pelatihan ini melibatkan 10 orang masyarakat yang berada di desa Ampalu dan Apar. Mekanisme kegiatan diawali dengan pembekalan khusus bagi mahasiswa dan peserta pelatihan selam, sosialisasi kemasyarakat program wisata Bahari dengan Sapta Pesona, pelatihan pemandu wisata bagi warga disekitar wisata hingga uji kompetensi ditandai dengan perolehan sertifikat Scuba Diver jenjang A.1 oleh POSSI/CMAS. Tahap akhir adalah implementasi pemandu wisata dengan mengevaluasi pendapat pengguna (wisatawan) terhadap pemandu wisata yang telah lulus uji kompetensi. Hasil dari evaluasi menyatakan bahwa pemanduan berjalan sangat baik dan wisatawan merasa puas terhadap pelayanan pemandu wisata.
\end{abstract}

Kata Kunci: Wisata bahari, selam, pelatihan pemandu

\section{Abstract}

This paper describes the formation of tourism-conscious communities and trains international standard of marine tourism guides and establishes a guiding organizations that work professionally. This program is the goal of the KKN-PPM grant. This training involved 10 people in the Ampalu and Apar villages. The mechanism of the activity begins with special debriefing for students and diving training participants, socialization of the community of Bahari tourism programs with Sapta Pesona, training for tour guide in the residents around the tourist areas and finnely tests of competency for participants. They had take Scuba Diver certificates at the level A.1 by POSSI / CMAS. The final stage is the implementation of tour guides by evaluating the opinions of users (tourists) on tour guides who have passed the competency test. The evaluation result stated that scouting was very good and tourists feel satisfied with the services of tour guides.

Keywords: Marine Tourism, Diving, Tour Guide Training

\section{PENDAHULUAN}

Kota Pariaman resmi berdiri sebagai kota otonom pada tanggal 2 Juli 2002 berdasarkan Undang-undang Nomor 12 Tahun 2002 tentang pembentukan kota Pariaman di Propinsi Sumatera Barat. Sebelumnya kota ini masih berstatus kota administratif dan menjadi bagian dari kabupaten Padang Pariaman berdasarkan Peraturan Pemerintah Nomor 33 Tahun 1986 yang diresmikan tanggal 29 Oktober 
1987 oleh Mendagri Soepardjo Rustam dengan Walikota pertamanya Drs. Adlis Legan. Jumlah penduduk kota Pariaman secara keseluruhan hampir didominasi oleh etnis Minangkabau, dengan rasio jenis kelamin 93.26, sedangkan jumlah angkatan kerja 27.605 orang dengan jumlah pengangguran 2.970 orang. Secara geografis Kota pariaman terletak antara $0^{\circ} 33$ '00" - 0`40'43” Lintang Selatan dan $100^{\circ} 07^{\prime} 00^{\prime \prime}-100^{\circ} 10^{\prime} 55^{\prime \prime}$ Bujur Timur dengan luas $73 \mathrm{Km}^{2}$ yang terbagi dalam wilayah daratan dan kepulauan dan terdiri dari-, 4 (empat) Kecamatan yaitu Kecamatan Pariaman Utara, Kecamatan Pariaman Tengah, Kecamatan Pariaman Selatan dan Kecamatan Pariaman Timur. Kota ini memiliki empat buah pulau kecil yaitu: Pulau Kasiak, Pulau Angso, Pulau Tangah, Pulau Ujung dan Pulau Bando serta mempunyai 1 (satu) buah Gosong si Barat.

Kota Pariaman merupakan kota otonom yang merupakan salah satu dari 7 (tujuh) Kabupaten dan Kota di Sumatera Barat yang berada di pantai barat Sumatera dengan panjang garis pantai $12,73 \mathrm{Km}^{2}$ dengan luas perairan 282,69 $\mathrm{Km}^{2}$, Kota Pariaman memiliki pantai landai dengan pesona yang indah, saat ini resort wisata telah dibenahi oleh pemerintah daerah setempat dalam usaha pengembangan sektor pariwisatanya. Salah satu objek wisata pantainya adalah pantai Gandoriah yang berlokasi di depan stasiun kereta api kota dan objek wisata konservasi penyu yang berada pada pantai konservasi penyu di desa Apar kota Pariaman.

Terkait dengan wisata bahari yang ada selama ini, wisatawan yang datang ke kota pariaman hanya berkunjung ke pantai konservasi penyu saja dan itu pun mereka tidak mendapatkan pelayanan apa-apa dari masyarakat di pantai dan masyarakat disekitar konservasi tidak mengetahui dan tidak dapat menjelaskan hal-hal yang terkait dengan komponen-komponen yang ada di pantai konservasi penyu. Selanjutnya, dengan adanya kunjungan ke pantai konservasi penyu tersebut merupakan peluang bagi masyarakat untuk mempublikasikan tempattempat wisata budaya yang lainnya yang berada disekitarnya, khususnya wisata alam bawah laut. Masyarakat yang kreatif akan dapat menimbulkan daya tarik terhadap wisatawan yang datang, baik dari dalam maupun luar negeri. Langkahlangkah yang dapat ditempuh masyarakat adalah dengan cara memperkenalkan 
pada wisatawan yang datang kekayaan wisata yang ada di daerah Kota Pariaman melalui wisata pantai. Kondisi alam bawah laut yang ada di Pariaman tidak kalah indahnya dengan wisata alam bawah laut yang ada di Pulau Bali. Permintaan wisata alam bawah laut terus mengalami peningkatan sehingga tidak dapat terlayani oleh tenaga yang tersedia. Pemandu yang ada saat ini hanya secara spontanitas dari tenaga yang ada pada dinas Kelautan dan Perikanan kota Pariaman yang kebetulan pengelola konservasi Penyu dan hanya 1 (satu) orang yang memiliki sertifikat pemandu wisata alam bawah laut.

Hasil observasi dilapangan dan pertemuan Tim dengan Wakil Walikota Pariaman Dr. Genius Umar, M.Si dan Kepala UPT Konservasi Penyu bahwa di Kota Pariaman belum ada pemandu wisata bahari yang profesional dan organisasi yang menaungi pemandu wisata tersebut. Pemandu wisata yang ada hanya bersifat spontanitas dari pegawai yang ada di UPT. Konservasi Penyu. Sementara saat ini Pemerintah sedang gencar untuk memperkenalkan pesona dan keindahan biota bawah laut ke masyarakat. Sementara banyak wisatawan yang ingin menikmati keindahan bawah laut kota Pariaman, namun mereka tidak terlayani karena kurangnya pemandu wisata yang bawah laut yang profesional.

Berdasarkan permasalahan tersebut, maka perlu dicarikan solusinya, yaitu adanya upaya untuk menggiatkan wisata bahari, khususnya untuk melaksanakan pelatihan khusus bagi masyarakat di sekitar pantai koservasi penyu terkait bagaimana menjadi pemandu wisata yang baik, khususnya wisata alam bawah laut yang bersertifikat Internasional scuba diver jenjang A.1 POSSI/CMAS. Dengan adanya pelatihan ini maka objek wisata Bahari di Kota Pariaman sudah siap untuk dipromosikan kewisatawan nasional dan mancanegara sehingga juga berimplikasi terhadap kehidupan masyarakat disekitarnya. Dengan demikian, tujuan kegiatan ini bersamaan dengan kegiatan KKN-PPM universitas Bung Hatta antara lain: (1) Membentuk organisasi pemandu wisata bawah laut yang profesional; (2) Melatih dan menghasilkan pemandu wisata bawah laut profesinal yang bersertifikat Internasional Scuba Diver jenjang A.1 POSSI/CMAS sebanyak 10 orang; dan (3) Menjadikan masyarakat Kota Pariaman yang sadar wisata dengan sapta pesonanya. 
Dengan adanya kegiatan pelatihan ini, maka beberapa manfaat yang dapat dirasakan adalah: (1) Meningkatnya jumlah wisatawan yang berkunjung ke Kota Periaman untuk menikmati pesona dan keindahan bawah laut karena sudah adanya pemandu wisata bawah laut yang profesional; dan (2) Terwujudnya program kerja pemerintah yang menjadikan kota Pariaman sebagai kota wisata Bahari.

Pengembangan kawasan wisata bahari dan bawah laut, sedang marak digalakkan dibeberapa daerah diantaranya yang dilakukan oleh (Agus, 2019; Cindy S. Walandouw et al, 2016; Mandeij, 2017; Syafikri et al., 2018). Namun untuk pengembangan wisata pantai dan bawah laut belum terlalu banyak, seperti yang dikemukakan oleh Aswita et al., (2017) dan Roberth, et al, (2019). Meskipun lokasi pengembangan didaerah kawasan pantai, namun karakteristik dan corak biota laut yang terdapat didalamnya mempunyai bentuk dan jenis yang berbeda. Bahkan dapat dijadikan sebagai sarana untuk pengembangan keolahragaan seperti yang dikemukakan oleh Sri Gusti Handayani, et al (2018). Dengan menggeliatnya usaha wisata Bahari di desa Apar Pariaman maka dapat meningkatkan perekonomian masyarakat sekitar konservasi Penyu karena jumlah wisatawan yang berkunjung lebih banyak, seperti yang telah dikembangkan oleh I Wayan \& I G A, (2015).

\section{METODE}

Program ini melibatkan mahasiswa KKN maka dilaksanakan dengan langkah-langkah yaitu: (1) persiapan yang terdiri dari: rekruitmen mahasiswa peserta KKN-PPM, pembekalan mahasiswa peserta KKN-PPM, dan sosialisasi program KKN-PPM ke desa Apar Kotamadya Pariaman. (2) Pelaksanaan yang terdiri dari: penerjunan mahasiswa ke lokasi KKN-PPM, pelatihan bagaimana teknik dalam memandu wisatawan yang datang ke tempat objek wisata, baik dari dalam maupun luar negeri, pelatihan bagaimana pengelolaan wisata bahari yang baik bagi peserta pemandu, dan pelatihan kemampuan pemandu wisata alam bawah laut bagi kelompok masyarakat dengan kapasitas terbatas. (3) Evaluasi 
yang terdiri dari dari: evaluasi dan monitoring pelaksanaan kegiatan, dan pembuatan laporan.

Secara singkat mekanisme palaksanaan kegiatan pelatihan pemandu selam melalui hibah KKN-PPM dapat dilihat pada gambar 1.

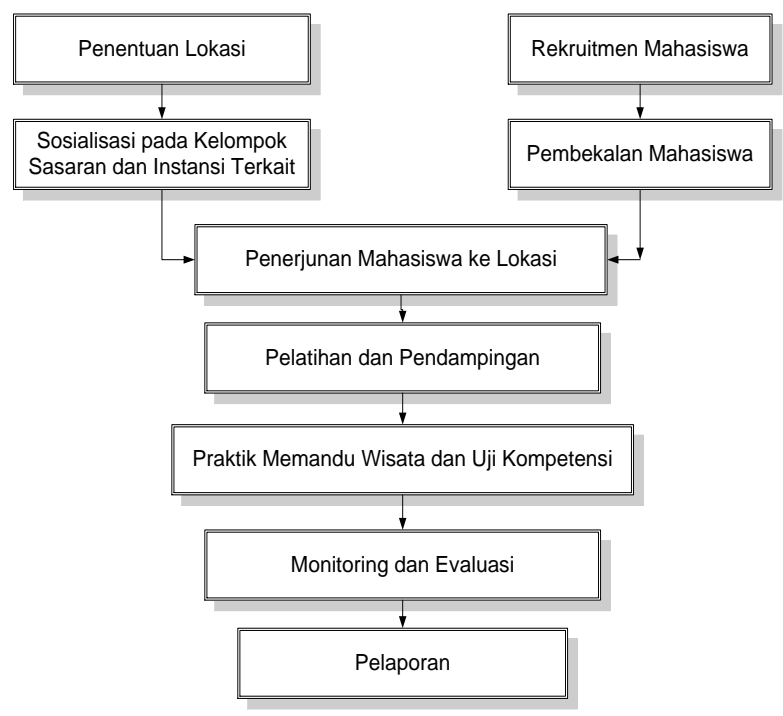

\section{Gambar 1. Mekanisme Pelaksanaan Kegiatan Hibah KKN-PPM}

\section{HASIL DAN PEMBAHASAN}

Pelatihan pemandu selam sudah dimulai sejak 1 Juni 2015 dengan pemberian latihan dasar renang dan selam. Kemudian dilanjutkan dengan latihan praktek selam di perairan tertutup (kolam renang Nantongga dan Teratai) dan di perairan terbuka (di pulau Kasiak). Diantara latihan praktek juga diikuti dengan teori-teori dasar penyelaman. Sebelum peserta mengikuti sertifikasi selam jenjang A.1 POSSI/CMAS maka seluruh peserta diwajibkan untuk mengisi pernyataan riwayat kesehatan penyelam yang diketahui oleh orang tua dan ditanda tangani di atas materai $\mathrm{Rp}$ 6.000. Hal ini bertujuan untuk mengetahui apakah peserta diperbolehkan untuk mengikuti sertifikasi selam dan Pada tanggal 14 Agustus 2015 dengan adanya instruktur selam dari POSSI maka dilaksanakan tes tertulis yang merupakan persyaratan awal uji kompetensi. Pada ujian teori semua peserta dinyatakan lulus dan dilanjutkan dengan ujian praktek yang dilaksanakan pada tanggal 15 Agustus 2015 di kolam renang Teratai, tanggal 16 Agustus 2015 di 
Pulau Kasiak dan tanggal 17 Agustus 2015 di pulau Pasumpahan. Kegiatan pelatihan selam terlihat pada gambar 2 .

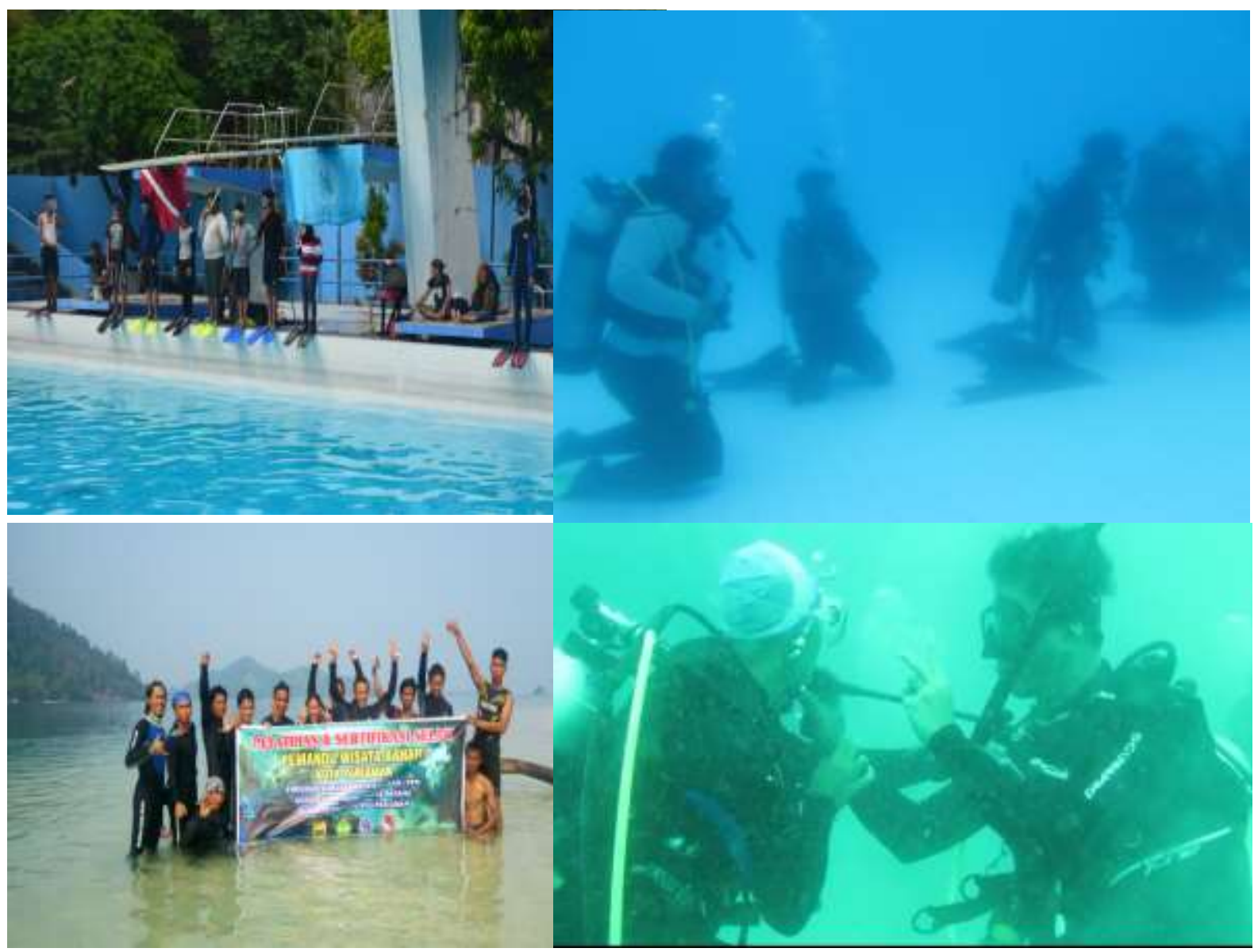

Gambar 2. Kegiatan Pelatihan Selam

Berdasarkan uji praktek yang langsung dievaluasi oleh instruktur POSSI maka semua peserta dinyatakan lulus memperoleh kartu anggota Scuba Diver dan sertifikasi selam jenjang A.1 dan semua peserta secara otomatis menjadi anggota organisasi selam POSSI/CMAS. Kartu anggota dan sertifikat A.1 seperti gambar 3. 


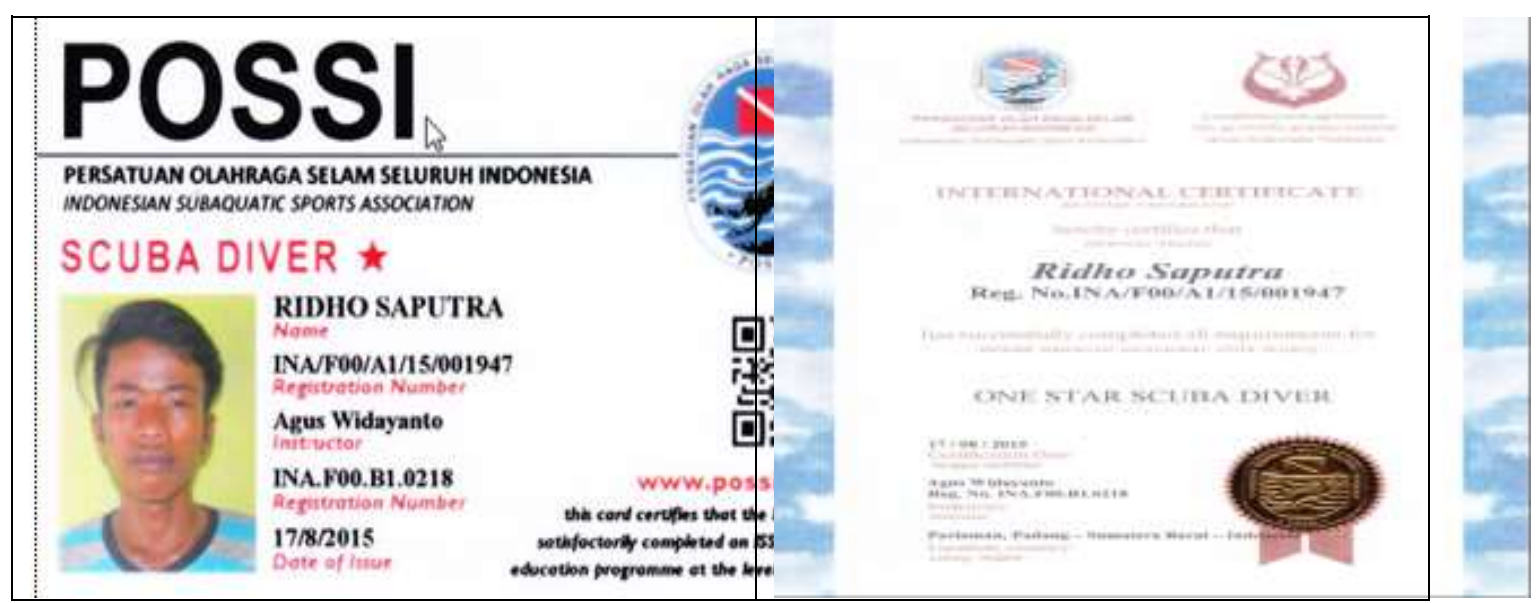

Gambar 3. Kartu anggota Scuba Diver dan Sertifikat

Dipihak lain, dengan bantuan mahasiswa KKN-PPM, maka sudah terbentuk anggaran dasar dan anggaran rumah tangga organisasi selam kota Pariaman yang disebut Tabuik Diving Club (TDC) dan sudah terbentuk struktur organisasi TDC dengan pengurus seperti pada lampiran 4 TDC ini akan diupayakan menjadi organisasi yang berbadan hukum.

Pada tanggal 19 dan 20 September 2015, telah dilaksanakan implementasi praktek memandu wisatawan yang berasal dari Malaysia. Wisatawan Malaysia berjumlah 10 orang dan ada 2 orang yang ingin melakukan penyelaman yang dipandu oleh 2 orang pemadu selam. Dari hasil wawancara dengan wisatawan setelah kegiatan penyelaman menyatakan bahwa pemandu selam melaksanakan pemanduan penyelaman dengan baik dan mereka merasa puas terhadap pelayanan yang diberikan. Kegiatan implementasi selanjutnya pada tanggal 26 September 2015 dengan memandu mahasiswa yang sedang melakukan penelitian bawah laut. Mahasiswa yang dipandu merasa puas dengan hasil yang diperolehnya selama meneliti di daerah tersebut.

Selain itu, peran mahasiswa KKN Universitas Bung Hatta adalah melatih para ibu-ibu ramah tangga dalam menghasilkan cendramata dengan bahan dasar benda-benda yang tebuang dan bahan yang ada di daerah tersebut yang berbentuk penyu. Hasil karya souvenir tersebut seperti pada gambar 4. 


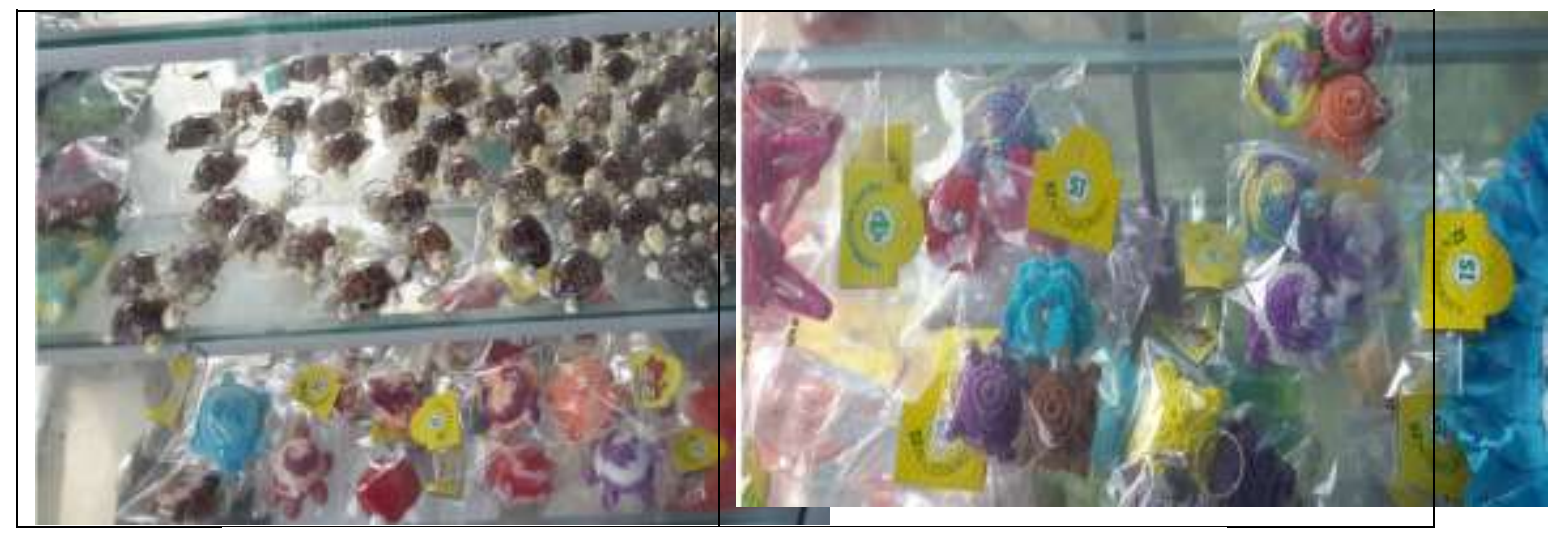

Gambar 4. Cendramata Hasil Pelatihan dari Mahasiswa

\section{SIMPULAN}

Dari kegiatan ini, sesuai dengan target dapat diambil kesimpulan, yaitu kegiatan Pelatihan pemandu wisata Bahari telah menghasilkan 10 (sepuluh) orang pemandu selam professional yang sudah bersertifikat selam jenjang A.1 POSSI/CMAS. Dipihak lain, karena kegiatan pelatihan ini melibatkan mahasiswa KKN-PPM, maka dapat memberikan penyuluhan sadar wisata dan menggerakkan masyarakat sekitar tempat wisata untuk memahami program Sapta Pesona sehingga sebagian masyarakat sudah berpartisipasi mensukseskan program pemerintah daerah dengan adanya kelompok masyarakat yang membuat cenderamata, penyediaan tempat menginap untuk wisatawan dan menyediakan makanan khas kota Pariaman disekitar tempat wisata. Untuk dapat melayani permintaan yang lebih professional maka kegiatan pelatihan selam yang sudah bersertifikat jenjang A.1 ini dapat dilanjutkan ke jenjang sertifikat yang lebih tinggi melalui rencana program dinas Perikanan dan Kelautan kota Pariaman , agar dapat menjadikan kawasan konservasi penyu sebagai pusat penelitian bagi mahasiswa dalam dan luar negeri. Untuk peningkatan kunjungan wisata lebih besar maka diperlukan promosi secara gencar melalui media masa bahkan pembuatan situs jaringan khusus seperti yang dikembangkan oleh Putra, et al ( 2011). 


\section{UCAPAN TERIMA KASIH}

Ucapan terima kasih diucapkan kepada Kemrisktekdikti yang telah memberi bantuan Hibah KKN dan juga kepada Pemerintah Daerah Kota Pariaman yang telah membantu dalam mempasilitasi penyediaan alat-alat selam untuk pelatihan serta tempat untuk mahasiswa KKN Universitas Bung Hatta.

\section{DAFTAR PUSTAKA}

Agus. (2019). Analisis daya dukung potensi wisata bahari baru di kawasan wisata pulau weh sebagai pulau terluar. PUSAKA: Journal of tourism, hospitality, travel and busines event, 1(2): 1-14.

Aswita, D., Samuda, S., Andalia, N., Biologi, P., Mekkah, U. S., Negara, I. A., Utara, M. (2017). Strategi pemanfaatan komunitas lokal dalam pantai Teupin Layeu Iboih. Jurnal ilmu sosial dan humaniora, 6(2): 159-167.

Cindy, S. Walandouw; Jardie A. Andaki; Olvie V. Kotambunan. (2016). Potensi ekowisata bahari di daerah perlindungan laut desa Bahoi kecamatan Likupang Barat Kabupaten Minahasa Utara. Akulturasi, 4(1): 217-227.

Handayani, S., G, Fajri, H. P. (2018). Pemberdayaan kelompok masyarakat dalam mengembangkan olahraga pariwisata di pulau Sirandah melalui pelatihan tenaga guide olahraga pariwisata. Stamina, 1(1): 380-390.

Mandeij, D. (2017). Kajian partisipasi masyarakat dalam mengembangkan wirausaha baru untuk mengelola pariwisata bahari di sulawesi utara. Jurnal berkala ilmiah efisiens, 17(3): 188-200.

Putra, C., Iriani, A., \& Manuputty, A. D. (2011). Perancangan dan implementasi e-tourism pada sistem. Jurnal teknologi informasi-aiti, 8(1): 74-86.

Roberth, E., Lau, A., \& Par, M. (2019). Potensi desa alor kecil sebagai desa wisata di Kabupaten Alor Nusa Tenggara Timur. JURNAL TOURISM, 2(1): 32-38.

Syafikri, D., Nurwahidah, S., Kautsari, N., Studi, P., Sumberdaya, M., Agribisnis, P. S., Bajo, L. (2018). Pengembangan ekowisata bahari dan budidaya rumput laut di kawasan konservasi sebagai upaya peningkatan pendapatan masyarakat. Prosiding PKM-CSR, 1, 1597-1609.

Wayan, I., S., \& I G A, S. D. (2015). Dampak Pariwisata terhadap mata pencaharian masyarakat pesisir karang asem:pendekatan pro poor tourism. Piramida, 11(2): 76-87. 